\title{
Comparison study between neural STSM and ANFIS-STSM method in DPC control scheme of DFIG-based dual-rotor wind turbines
}

\author{
Benbouhenni Habib $^{\# 1}$, Boudjema Zinelaabidine ${ }^{* 2}$, Belidi Abdelkader ${ }^{\# 3}$ \\ \#Laboratoire d'Automatique et d'Analyse des Systèmes (LAAS), Departement de Génie Électrique, Ecole Nationale Polytechnique d'Oran \\ Maurice Audin, Oran, Algeria. \\ 1habib0264@gmail.com \\ 3belaidiaek@gmail.com \\ * Electrical Engineering Department, Hassiba Benbouali University, Salem district 02000 Chlef, Algeria. \\ ²boudjemaa1983@yahoo.fr
}

\begin{abstract}
This work presents the comparison study between neural super-twisting sliding mode control (NSTSM) and adaptive-network-based fuzzy inference system-STSM (ANFIS-STSM) algorithm of the doubly fed induction generator (DFIG) controlled by direct power control (DPC). The mathematical model of the three-phase DFIG has been described. The descriptions of the DPC strategy, NSTSM and the ANFIS-STSM algorithm have been presented. The DPC strategy with NSTSM and ANFISSTSM has been described. The simulation studies of the DPC strategy with intelligent STSM algorithms have been performed, and the results of these studies are presented and discussed.
\end{abstract}

Keywords - Doubly fed induction generator, Direct power control, Neural super-twisting sliding mode control, Simulation studies, Adaptive-network-based fuzzy inference system.

\section{INTRODUCTION}

The development of variable structure systems (VSS) allows us to use a super-twisting sliding mode (STSM) algorithm instead of a traditional sliding mode controller (SMC). Major advantages of STSM algorithms are as follows: simple algorithm, insensitivity to parameters variation, fast dynamic response, and robust control compared to classical SMC method and other techniques.

Benbouhenni et al. [1], have proposed a second-order sliding mode controller (SOSMC) based on the fuzzy logic controller to control the doubly-fed induction generator (DFIG). This proposed strategy is a simple control scheme compared to the conventional SOSMC and SMC method. The simulation results have shown the superiority of the proposed method compared to direct vector control (DVC). Benbouhenni et al. [2-6], have designed the neural SOSMC method to minimize the reactive power ripple and harmonic distortion of stator current, the proposed SOSMC method has compared to classical SOSMC and DVC strategy under simulation. The simulation results have shown the superiority of the neural SOSMC method. A fuzzy SOSMC strategy technique was designed to control the DFIG-based wind turbines $[7,8]$. This proposed strategy is simple and robust compared to the traditional SOSMC method. In [9], the Fuzzy SOSMC method minimized the reactive and active power ripples compared to the fuzzy SMC strategy. In [10], the fuzzy SMC strategy and space vector pulse width modulation (SVPWM) were combined to reduce the harmonic distortion of stator current and torque ripple of DFIG. In [11], fuzzy SMC was designed based on the neural SVPWM technique to regulate the active and reactive power of DFIG. Benbouhenni et al. [12, 13], have presented a neural SMC method to control the DFIG that is compared with the conventional SMC method in terms of elimination of the power ripple and torque ripple. The simulation results indicate that the neural SMC method showed better performance with reducing the reactive power ripple, active power ripple and torque ripple when it is compared with the traditional SMC technique. The author of the study [14-16], has used a neural SMC strategy based on neural SVPWM and fuzzy PWM technique to control the active and reactive power of DFIG-based wind turbine systems. The simulation results show that the neural SMC strategy is robust when used the fuzzy PWM technique. In [17], the neural SOSMC method reduced the torque ripple, reactive and active power ripples compared to the neural SMC strategy. The author of the study [18], has used an adaptive-network-based fuzzy inference system-SOSMC (ANFIS-SOSMC) to control the DFIG. The simulation results show that the ANFIS-SOSMC method is better than the traditional SOSMC strategy in terms of minimizing the torque ripple, active and reactive power. In [19], the ANFIS-SMC strategy minimized the torque ripple and active power ripple compared to the traditional SMC method. As another intelligent SOSMC method, is proposed to control the DFIGbased wind turbine [20-23]. Listwan [24], has presented the direct field-oriented control (DFOC) based on the STSM algorithm to control the six-phase induction motor using the SVPWM technique. The experimental results indicate that the DFOC with STSM algorithm showed better performance by reducing the torque ripple and flux ripple when it is compared with the DFOC strategy. In [25], the author has used the 
STSM controllers based on the SVPWM technique to control the DFIG-based wind turbine systems. In [26], A secondorder continuous sliding mode was proposed to control the DFIG. An SMC method was designed to control the dual rotor wind turbine (DRWT) system [27].

Traditional field-oriented control (FOC) using proportional-integral (PI) regulators is the classical method used for DFIG [28-30]. This method is a simple structure and easy to implement $[31,32]$. But, this method needs accurate values of DFIG parameters and rotor speed [33, 34]. On the other hand, this control scheme gives more torque ripple, reactive power ripple, active power ripple and harmonic distortion of stator current [35]. In [36], direct vector control (DVC) was proposed based on the five-level fuzzy SVPWM technique, where a hysteresis comparator was proposed based on fuzzy controllers. An indirect vector control (IVC) is designed based on the four-level fuzzy SVPWM technique to regulate the active/reactive power of DFIG [37]. In [38], the DVC method based on the intelligent SVPWM technique has been proposed. In [39], seven-level neural SVPWM is proposed to improve the DVC method. In [40], the IVC method was proposed based on the five-level fuzzy SVPWM technique to control the DFIG. In [41], a robust DVC method were proposed based on the four-level neural SVPWM technique, where the hysteresis comparators was proposed based on neural algorithms. In [42], the IVC method minimized the reactive power ripple, active power ripple and torque ripple compared to DVC method. In [43], the IVC method was proposed based on the three-level neural SVPWM and four-level neural SVPWM technique. In [44], the IVC method was proposed based on the two-level fuzzy PWM technique to control the DFIG. In [45], the IVC strategy was proposed based on the three-level neural SVPWM technique to regulate the reactive power and active power the DFIG. In [46], the DVC method was proposed based on the five-level neural SVPWM and two-level neural SVPWM techniques.

Since, direct power control (DPC) techniques have gained importance in the recent past due to their fast response, simple algorithm, good dynamic response, and superior method characteristic. In the traditional DPC method, reactive and active power can be directly controlled by using hysteresis comparators and switching tables. Nevertheless, a few disadvantages limit the use of these comparators, such as reactive power ripple, torque ripple, active power ripple and switching frequency [47]. In [48], the DPC method was proposed to improve the dynamic response of the DFIGbased wind energy generation systems (WEGS). In [49], the DPC method was proposed based on under distorted grid voltage conditions. A DPC method based on stator flux estimation was designed to control the DFIG-WECS [50]. In [51], the DPC method was proposed to reduce the harmonic distortion of stator current. In [52], the DPC method based on two-level SVPWM technique has been proposed. In [53], the DPC strategy with intelligent control was presented. A DPC method was designed to control the permanent magnet synchronous generator (PMSG) based variable speed wind energy conversion (WEC) [54, 55]. In [56], the DPC method based on the discrete space vector modulation ( SVM) technique has been proposed. In [57, 58], two different DPC strategy of DFIG-WEC was presented. Benbouhenni et al. [59], have proposed a DPC method based on neural PI controllers and neural PWM technique to control the DFIGbased wind turbine. This proposed strategy is a simple algorithm and robust method compared to the traditional DPC method. The simulation results have shown the superiority of the proposed method compared to the classical DPC strategy. In [60], the twelve sectors DPC method was designed based on the neural hysteresis comparators to minimize the torque ripple, active power ripple, reactive power ripple and harmonic distortion of stator current. The proposed DPC method has compared to classical DPC and FOC method under simulation. The simulation results have shown the superiority of the proposed control method. A DPC control scheme was designed based on neural PI controllers to control the DFIG-based wind turbines [61]. In [62], the DPC method was proposed based on seven-level SVPWM technique. In [63], the five-level DPC method was proposed based on neural algorithm to control the DFIG, where, the switching table is replaced by neural controller. The proposed DPC minimized the harmonic distortion of stator current and reactive power ripple of the DFIG-based wind turbine. A DPC control scheme was designed based on three-level neural SVPWM technique to control the DFIG-based wind turbines [64]. In [65], the twelve sectors DPC method was designed based on neural algorithm, where the switching table and hysteresis comparators was replaced by neural algorithm. This method minimized the torque ripple, reactive power ripple, harmonic distortion of stator current and reactive power ripple compared to classical DPC method. A DPC method was designed based on neural STSM algorithm to control the DFIG-based wind turbines [66]. In [67], DPC control scheme was proposed based on ANFIS-STSM algorithm, where the two PI controllers was proposed based on ANFIS-STSM controllers. This control scheme is simple algorithm and easy to implement. In [68], DPC method was proposed based on discrete SVPWM technique to control the DFIG.

In this work, two different strategies will be compared with each other. These strategies are DPC method using neural STSM algorithm and DPC strategy using ANFIS-STSM algorithm. The original contribution of this work is the application of the intelligent STSM algorithms in the DPC strategy with DFIG-DRWT and simulation investigation of this method.

This work is divided into seven sections. In Section 1, the introduction is presented. In Section 2, the mathematical model of the DFIG is described. The dual-rotor wind turbine has been discussed in Section 3. In Section 4, the description of the intelligent STSM algorithm is presented. Section 5 deals with the description of the DPC strategy with the application of intelligent STSM algorithms. Simulation studies are presented and discussed in Section 6. The work is concluded with a short summary. 


\section{MATHEMATICAL MODEL OF DFIG}

Mathematical model of the DFIG has been presented in detail in $[69,70]$. The DFIG dynamic can be represented by the Park's equations.

Rotor voltage components :

$\left\{\begin{array}{l}V_{d r}=R_{r} I_{d r}+\frac{d}{d t} \psi_{d r}-\omega_{r} \psi_{q r} \\ V_{q r}=R_{r} I_{q r}+\frac{d}{d t} \psi_{q r}+\omega_{r} \psi_{d r}\end{array}\right.$

Where : $\mathrm{V}_{\mathrm{dr}}$ and $\mathrm{V}_{\mathrm{qr}}$ are the rotor voltages.

$\mathrm{R}_{\mathrm{r}}$ is the rotor resistance.

Rotor flux components :

$\left\{\begin{array}{l}\psi_{d r}=L_{r} I_{d r}+M I_{d r} \\ \psi_{q r}=L_{r} I_{q r}+M I_{q r}\end{array}\right.$

Where : $\Psi_{\mathrm{dr}}$ and $\Psi_{\mathrm{gr}}$ are the rotor fluxes

$\mathrm{L}_{\mathrm{r}}$ is the inductance of the rotor

$\mathrm{M}$ is the mutual inductance

$\mathrm{I}_{\mathrm{dr}}$ and $\mathrm{I}_{\mathrm{qr}}$ are the rotor currents.

Stator voltage components :

$\left\{\begin{array}{l}V_{d s}=R_{s} I_{d s}+\frac{d}{d t} \psi_{d s}-\omega_{s} \psi_{q s} \\ V_{q s}=R_{s} I_{q s}+\frac{d}{d t} \psi_{q s}+\omega_{s} \psi_{d s}\end{array}\right.$

Where : $\mathrm{V}_{\mathrm{ds}}$ and $\mathrm{V}_{\mathrm{qs}}$ are the stator Voltages

$\mathrm{R}_{\mathrm{S}}$ is the stator resistance

$\omega_{s}$ : is the electrical pulsation of the stator.

Stator flux components :

$\left\{\begin{array}{l}\psi_{d s}=L_{s} I_{d s}+M I_{d r} \\ \psi_{q s}=L_{s} I_{q s}+M I_{q r}\end{array}\right.$

Where : $\Psi_{\mathrm{qs}}$ and $\Psi_{\mathrm{ds}}$ are the stator fluxes.

$\mathrm{L}_{\mathrm{s}}$ is the inductance of the stator.

The torque can be written as follows:

$T_{e}=\frac{3}{2} p \frac{M}{L_{r}}\left(I_{d r} \cdot \psi_{q s}-I_{q r} \cdot \psi_{d s}\right)$

Where $: p$ is the number of pole pairs.

$\mathrm{T}_{\mathrm{e}}$ is the electromagnetic torque

The stator side active and reactive powers are defined as:

$\left\{\begin{array}{l}P_{s}=\frac{3}{2}\left(V_{d s} I_{d s}+V_{q s} I_{q s}\right) \\ Q_{s}=\frac{3}{2}\left(V_{q s} I_{d s}-V_{d s} I_{q s}\right)\end{array}\right.$

Where: $\mathrm{P}_{\mathrm{s}}$ is the stator active power

$\mathrm{Q}_{\mathrm{s}}$ is the stator reactive power.

The electrical model of the DFIG is completed by the following mechanical equation:

$T_{e}-T_{r}=J \cdot \frac{d \Omega}{d t}+f \cdot \Omega$
Where $: \Omega$ is the mechanical rotor speed.

$J$ is the inertia

$f$ is the viscous friction coefficient

$T_{r}$ is the load torque.

\section{DUAL ROTOR WIND TURBINE}

In the analyzed wind turbine, it is assumed that dual rotor wind turbine is consists by two rotors wind turbine. The DRWT has been proposed as a novel wind for improvement of power efficiency, as shown in Figure 1. The ideal maximum power coefficient (Cp) of the DRWT is 64\% compared to a single rotor is about 59\% [71]. On the other hand, the total aerodynamic torque of DRWT is the Auxiliary turbine add to the Main turbine torque as shown by the following equation :

$T_{D R W T}=T_{T}=T_{M}+T_{A}$

Where : $\mathrm{T}_{\mathrm{M}}$ : Main turbine torque.

$\mathrm{T}_{\mathrm{A}}$ : Auxiliary turbine torque.

$\mathrm{T}_{\mathrm{T}}$ : Total torque.

The aerodynamic torque of the Auxiliary turbine is given :

$T_{A}=\frac{1}{2 \lambda_{A}^{3}} \cdot A \cdot \rho \cdot \pi \cdot R_{A}^{5} \cdot C_{p} \cdot w_{A}^{2}$

The aerodynamic torque of the Main turbine is given :

$T_{M}=\frac{1}{2 \lambda_{M}^{3}} \cdot A \cdot \rho \cdot \pi \cdot R_{A}^{5} \cdot C_{p} \cdot w_{M}^{2}$

With Ra, RM : blade radius of the main and auxiliary turbines, $\lambda_{\mathrm{A}}, \lambda_{\mathrm{M}}$ : the tip speed ration of the main and auxiliary turbines, $\rho$ : the air density and $w_{M}, w_{A}$ the mechanical speed of the main and auxiliary rotors.

The $\mathrm{Cp}$ of a DRWT is given :

$C_{p}(\lambda, \beta)=\frac{1}{\lambda+0.08 \beta}-\frac{0.035}{\beta^{3}+1}$

With $\beta$ is pitch angle

The tip speed ratios for the main and auxiliary turbines are calculated through (12) and (13), respectively.

$\lambda_{A}=\frac{w_{A} \cdot R_{A}}{V_{1}}$

$\lambda_{M}=\frac{w_{M} \cdot R_{M}}{V_{M}}$

Where $\mathrm{V}_{1}$ is the wind speed on an AWT and $\mathrm{V}_{M}$ is the speed of the unified wind on main turbine. On the other hand, the essential element for calculating the tip speed ratio is wind speed on the main and auxiliary turbines. Obtaining the wind speed on the auxiliary turbine is straight forward. However, calculation of wind speed on the main turbine requires further investigation. Based on the (14), it is possible to estimate the amount of the wind speed at any point between the auxiliary and main blades.

$V_{x}=V_{1}\left(1-\frac{1-\sqrt{\left(1-C_{T}\right)}}{2}\left(1+\frac{2 \cdot x}{\sqrt{1+4 \cdot x^{2}}}\right)\right)$

With $\mathrm{x}$ : the non-dimensional distance from the auxiliary rotor disk, $\mathrm{Vx}$ the velocity of the disturbed wind between rotors at 
point $\mathrm{x}$ and $\mathrm{C}_{\mathrm{T}}$ the trust coefficient, which is taken to be 0.9 . So, with respect to $\mathrm{x}=15$, the value of the $\mathrm{Vx}$ close to the main rotor is computable (rotors are located 15 meters apart from each other) [27]. where $K_{1}$ and $K_{2}$ are the coefficients of the proportional and integral parts of the STSM algorithm; $S$ is the switching function determined for the STSM algorithm, respectively; $r$ is the exponent defined for the STSM algorithm.

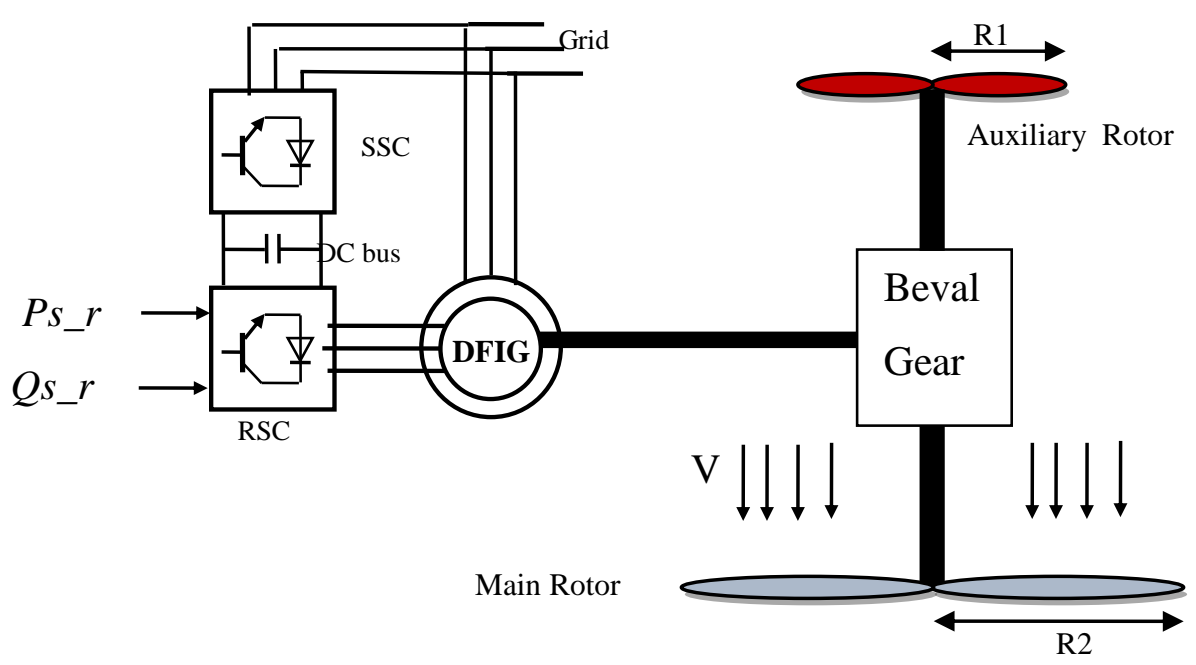

Figure 1. Block diagram of DRWT with a DFIG.

\section{IV.DESCRIPTION OF THE INTELLIGENT STSM ALGORITHMS}

The STSM algorithm maintains the advantages of the traditional SMC techniques and allows for the elimination of the undesirable phenomena of chattering. This method was proposed by Utkin et al., in 1999 [66]. The output signal from controller of this type is comparable with the control signal obtained from linear PI regulators. The control law of the STSM algorithm can be defined as follows:

$\left\{\begin{array}{c}u=K_{1}|S|^{r} \operatorname{sgn}(S)+u_{1} \\ \frac{d u_{1}}{d t}=K_{2} \operatorname{sgn}(S)\end{array}\right.$
The graphical representation of the control law of the STSM algorithm is shown in Figure 2.

The disadvantage of STSM algorithms of the DFIGDRWT is that the electromagnetic torque ripple, active power ripple, harmonic distortion of stator current and reactive power ripple. In this work, two different intelligent STSM algorithms was proposed to improve the DPC method of the DFIG-DRWT.

One way to improve STSM algorithm performance is to combine it with neural and fuzzy logic controller to form a neural STSM and fuzzy STSM algorithm. The design of a STSM algorithm incorporating intelligent control helps in achieving minimized torque ripple, harmonic distortion of stator current, simple algorithm and robust control.

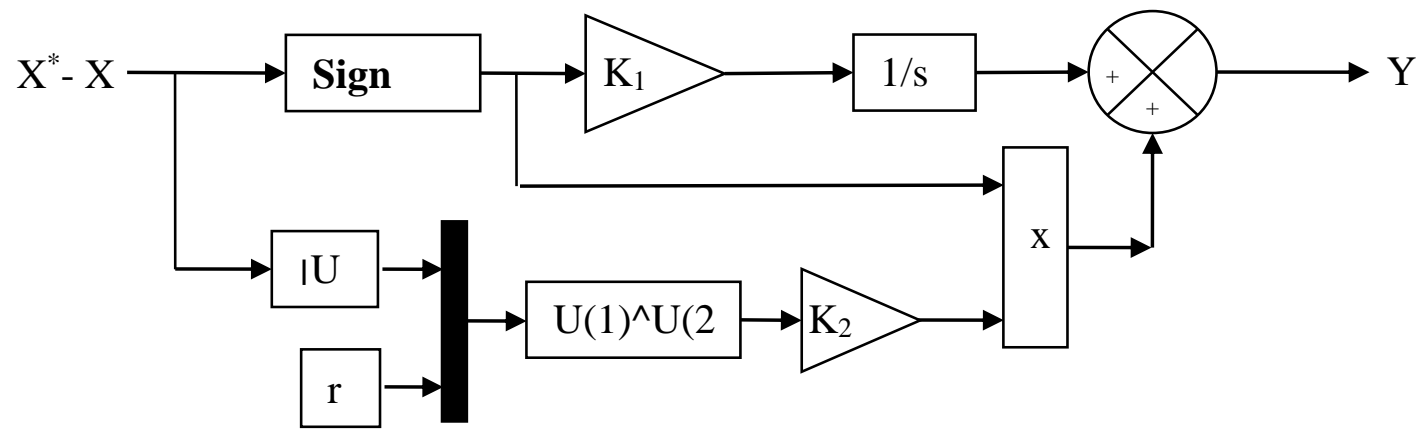

Figure 2. Graphical representation of the control law of the STSM algorithm. 
Neural algorithm is a method based on observations and engineering experience. In neural method, an exact mathematical model is not necessary. This technique is simple method and robust. The feedforward neural network (FNN) algorithm was the first type of neural network algorithm. This algorithm is similar to the conventional neural network $(\mathrm{CNN})$ algorithm, where the neurons have learnable weights and biases. Many studies [72-77] are oriented toward this type of algorithm to reduce the flux and torque ripples. Figure 3 shows the schematic block of a neural STSM algorithm. The principal of the neural STSM algorithm is similar to traditional STSM algorithm. However, the Sign(U) of traditional STSM algorithm is replaced by neural controller. This method based on neural classification has the advantage of simplicity and easy to implement.

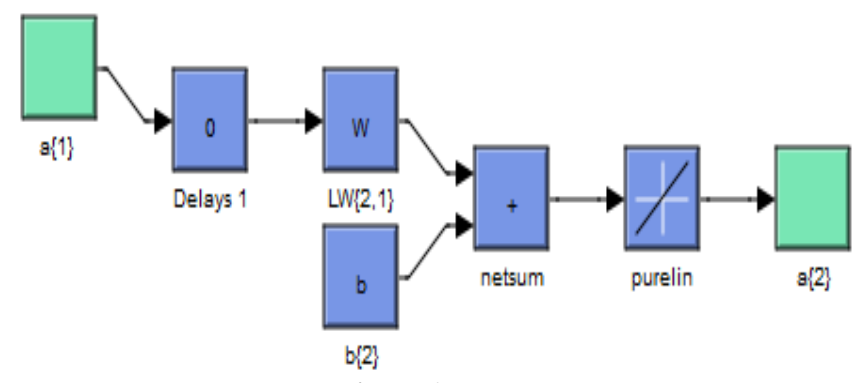

Figure 6. Layer 2.

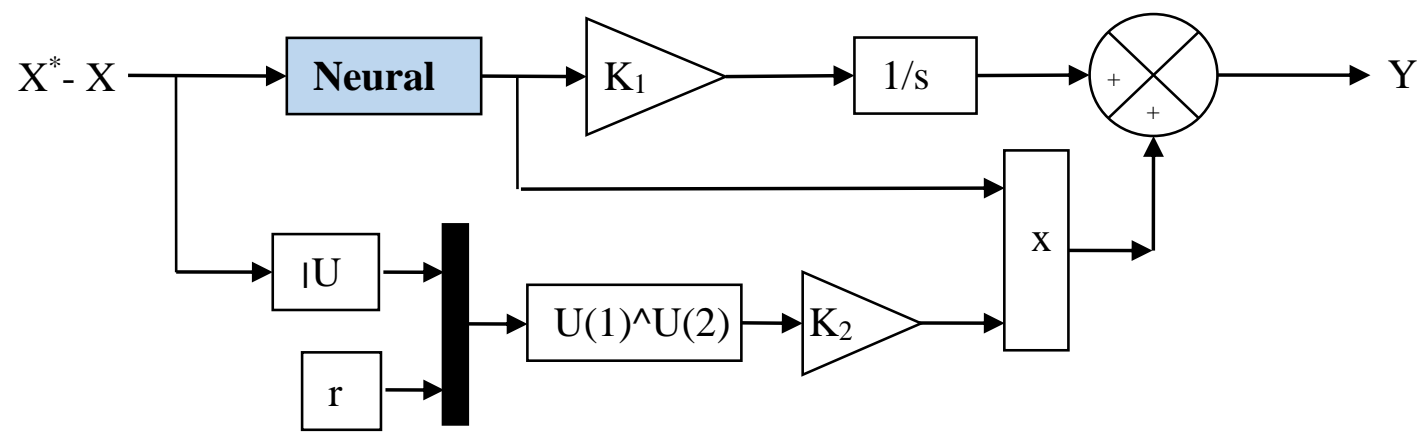

Figure 3. Neural STSM algorithm.

To make the FNN algorithm, we used the LevenbergMarquardt backpropagation (LMB) algorithm. This algorithm is simple and easy to use. In Matlab/Simulink, trainlm is the word we use to accomplish this algorithm. The structure of the ANN controller is illustrated in the Figure 4. The block diagram of layer 1 and layer 2 is shown in Figure 5 and Figure 6 respectively. The parameters of the FNN algorithm for the STSM algorithm are shown in Table 1.

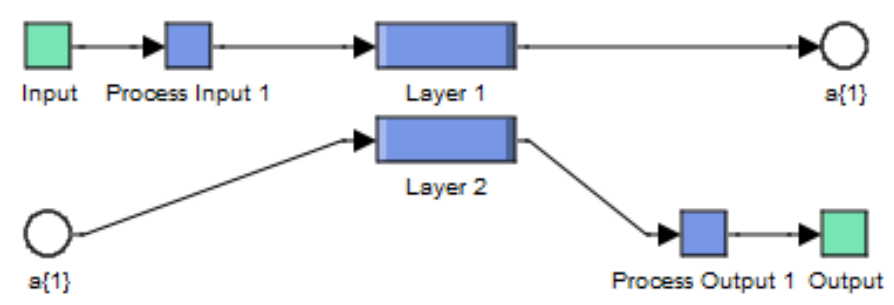

Figure 4. Block diagram of the neural controller.

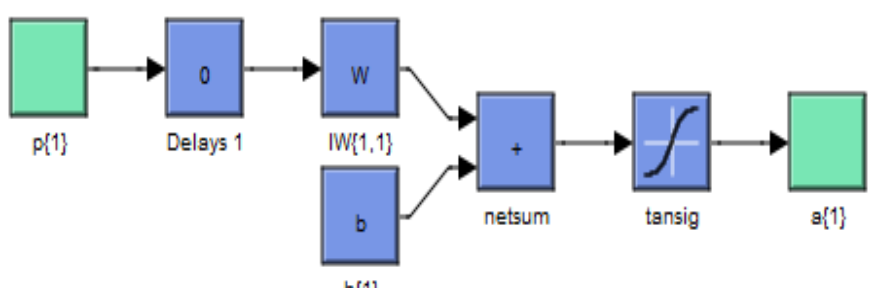

$b\{1\}$

Figure 5. Layer 1.
TABLE 1

PARAMETERS OF THE FNN ALGORITHM

\begin{tabular}{|l|c|}
\hline \multicolumn{1}{|c|}{ Parameters of the FNN } & Values \\
\hline Training & LMB algorithm (trainlm) \\
\hline TrainParam.Lr & 0.05 \\
\hline TrainParam.goal & 0 \\
\hline $\begin{array}{l}\text { Coeff of acceleration of } \\
\text { convergence (mc) }\end{array}$ & 0.9 \\
\hline Performances & Mean Squard Error (mse) \\
\hline TrainParam.mu & 0.8 \\
\hline TrainParam.show & 1000 \\
\hline TrainParam.eposh & 01 \\
\hline derivative & 08 \\
\hline Number of hidden layer & 01 \\
\hline Number of neurons in hidden layer & 01 \\
\hline Number of layer 1 & 01 \\
\hline Number of neurons in layer 1 & 01 \\
\hline Number of layer 2 & Densing, Purling, trainlm \\
\hline Number of neurons in layer 2 & \\
\hline Functions of activation & default deriv) \\
\hline
\end{tabular}

The STSM algorithm with the application of ANFIS controller is shown in Figure 7. In this method control, the Sign(U) control is replaced by ANFIS controller. However, this technique is a simple algorithm, robust control and reduced power ripple, torque ripple compared to traditional STSM algorithm. 


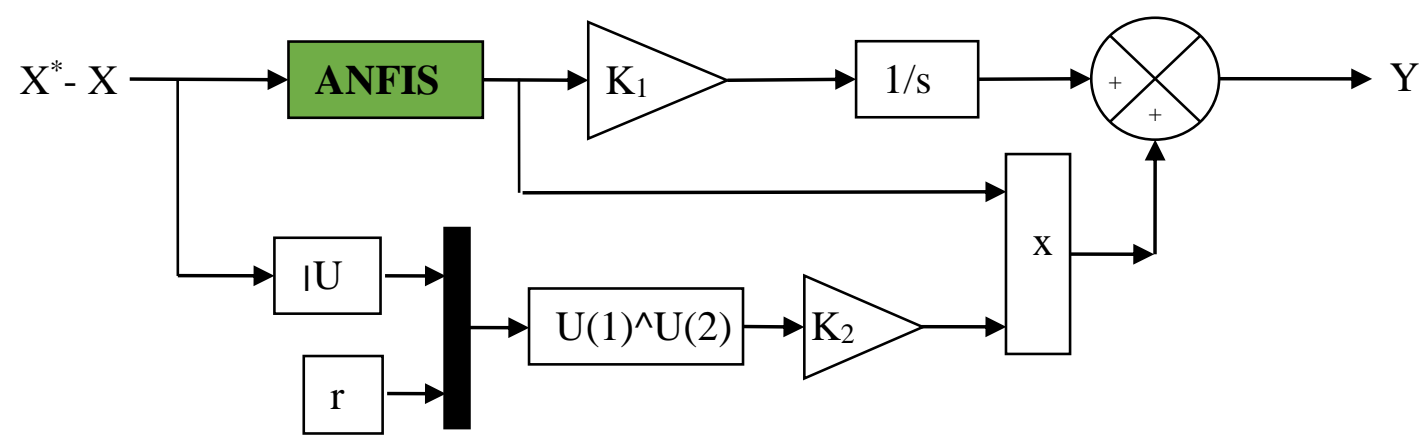

Figure 7. ANFIS-STSM algorithm.

The block diagram of ANFIS controller is shown in Figure 8. ANFIS architecture was first proposed by Jang [78] in 1993. This strategy is a widely applied artificial intelligent that combines the advantages of both ANN controller and fuzzy logic (FL) it is generally used for nonlinear and complex systems in various fields [79, 80]. The ANFIS rules for the proposed system are given in Table 2 [81-83]. The membership function definition is shown in Figure 9. We use the next designations for membership functions:

NB: Negative Big.

NM: Negative Middle.

NS: Negative Small.

PS: Positive Small.

PB: Positive Big.

EZ: Equal Zero.

PM: Positive Middle.

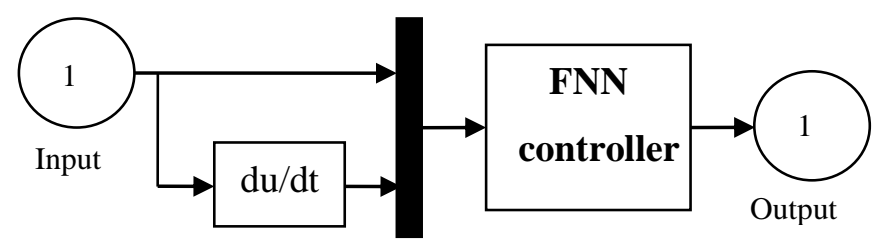

Figure 8. ANFIS controller.

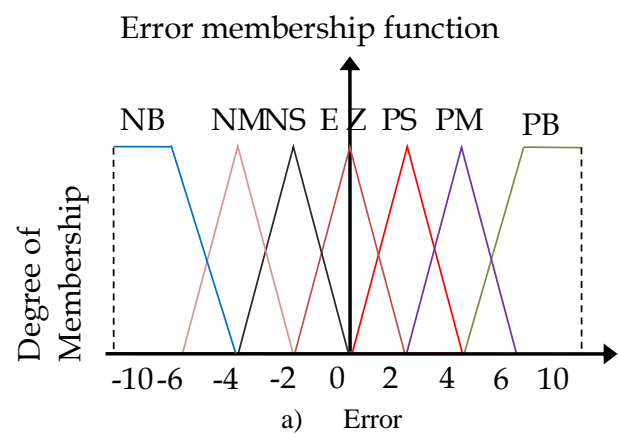

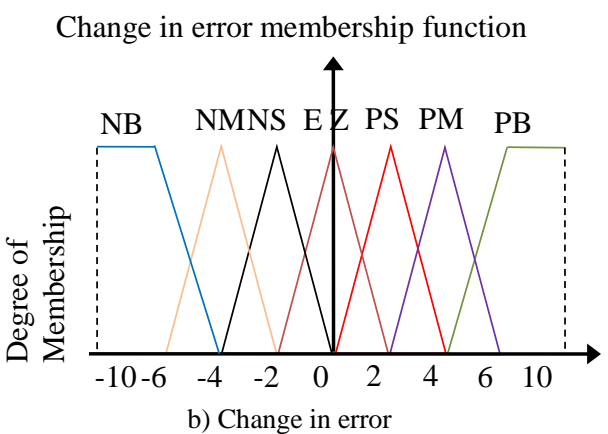

Figure 9. Membership functions.

TABLE 2

ANFIS RULS

\begin{tabular}{|l|l|l|l|l|l|l|l|}
\hline $\mathbf{e}$ & NB & NM & NS & EZ & PS & PM & PB \\
\cline { 1 - 5 }$\Delta \mathbf{e}$ & & & & & & & \\
\hline NB & NB & NB & NB & NB & NM & NS & EZ \\
\hline NM & NB & NB & NB & NM & NS & EZ & PS \\
\hline NS & NB & NB & NM & NS & EZ & PS & PM \\
\hline EZ & NB & NM & NS & EZ & PS & PM & PB \\
\hline PS & NM & NS & EZ & PS & PM & PB & PB \\
\hline PM & NS & EZ & PS & PM & PB & PB & PB \\
\hline PB & EZ & PS & PM & PB & PB & PB & PB \\
\hline
\end{tabular}

\section{INTELLIGENT STSM DPC STRATEGY}

The DPC strategy of the DFIG with the application of intelligent STSM algorithms is shown in Figure 10. In this method, the reactive and active powers are controlled by the intelligent STSM algorithms. On the other hand, the DPC goal is to minimizes the active and reactive powers ripples of the DFIG-DRWT compared to FOC method. This method is based on the same strategy principles as in the direct torque control (DTC). In DTC method, it's the rotor flux and the electromagnetic torque which are directly controlled, while in DPC strategy, it's the reactive and active stator powers, which are directly controlled [64]. The main advantages of the DPC strategy are its simple control scheme, easy to implement, superior method Characteristic, good dynamic response and robust method compared to vector control scheme. But, this method gives more harmonic distortion of 
stator current, active power ripple, torque ripple and reactive power ripple of the DFIG-DRWT. To obtain high performance DPC method, a simple algorithm and intelligent STSM algorithm is designed to minimizes the reactive and active power ripples.

In this work, a DPC method of the DFIG-based DRWT is presented. The DPC is proposed based on intelligent STSM algorithm to regulate the reactive power, harmonic distortion of stator current, torque and active power. Two intelligent STSM algorithms are selected to describe the switching surfaces for reactive and active power command. The intelligent STSM algorithm is designed to avoid the reaching phase stability problem. The proposed method preserves the advantages of the traditional DPC method such as simplicity, less parameters dependence and fast response. The stability of the STSM algorithm is proven using Lyapunov stability theorem.

Active and stator reactive powers is estimated using (16) and $(17)[63,68]$.

$P_{s}=-\frac{3}{2} \frac{L_{m}}{\sigma \cdot L_{s} \cdot L_{r}} \cdot\left(V_{s .} \psi_{r \beta}\right)$

$Q_{s}=-\frac{3}{2}\left(\frac{V_{s}}{\sigma \cdot L_{s}} \cdot \psi_{r \beta}-\frac{V_{s} \cdot L_{m}}{\sigma \cdot L_{s} \cdot L_{r}} \cdot \psi_{r \alpha}\right)$

Where: $\mathrm{Lm}$ is the mutual inductance

$\Psi_{\mathrm{r} \beta}:$ is the rotor flux linkage of $\beta$-axis.

$\Psi_{\mathrm{r} \alpha}$ : is the rotor flux linkage of $\alpha$-axis.

$\Psi_{s \alpha}=\sigma L_{r} I_{r \alpha}+\frac{M}{L_{s}} \Psi_{s}$

Where : $\Psi_{\mathrm{s} \alpha}$ : is the stator flux linkage of $\alpha$-axis.

$\Psi_{\mathrm{s}}$ is the stator flux.

$\mathrm{I}_{\mathrm{r} \alpha}$ : is the rotor current linkage of $\alpha$-axis.

$\Psi_{s \beta}=\sigma L_{r} I_{r \beta}$
Where : $\Psi_{\mathrm{s} \beta}$ : is the stator flux linkage of $\beta$-axis.

$\mathrm{I}_{\mathrm{r} \beta}$ : is the rotor current linkage of $\beta$-axis.

$\left|\overline{\Psi_{s}}\right|=\frac{\left|\overline{V_{s}}\right|}{w_{s}}$

Where : $\mathrm{V}_{\mathrm{s}}$ is the stator voltage.

$\sigma=1-\frac{M^{2}}{L_{r} L_{s}}$

Reactive and active powers can be reformulated by inducing angle $\lambda$ between the rotor and stator vectors as follows :

$P_{s}=-\frac{3}{2} \frac{L_{m}}{\sigma \cdot L_{s .} L_{r}} w_{s}\left|\psi_{s}\right| \psi_{r} \mid \sin (\lambda)$

$Q_{s}=-\frac{3}{2} \frac{w_{s}}{\sigma \cdot L_{s}}\left|\psi_{s}\right|\left(\frac{M}{L_{r}}\left|\psi_{r}\right| \cos (\lambda)-\mid \psi_{s}\right)$

The derivation of the active and reactive powers can given by:

$\frac{d P_{s}}{d t}=-\frac{3}{2} \frac{L_{m}}{\sigma \cdot L_{s} \cdot L_{r}} w_{s}\left|\psi_{s}\right| \frac{d\left(\left|\psi_{r}\right| \sin (\lambda)\right)}{d t}$

$\frac{d Q_{s}}{d t}=-\frac{3}{2} \frac{M \cdot w_{s}}{\sigma \cdot L_{r} L_{s}}\left|\psi_{s}\right|\left(\frac{d\left(\left|\psi_{r}\right| \cos (\lambda)\right)}{d t}\right)$

On the other hand, the magnitude of stator flux, which can be estimated by:

$\left\{\begin{aligned} \Psi_{s \alpha}= & \int_{0}^{t}\left(V_{s \alpha}-R_{s} I_{s \alpha}\right) d t \\ & 0 \\ \Psi_{s \beta}= & \int_{0}^{t}\left(V_{s \beta}-R_{s} I_{s \beta}\right) d t\end{aligned}\right.$

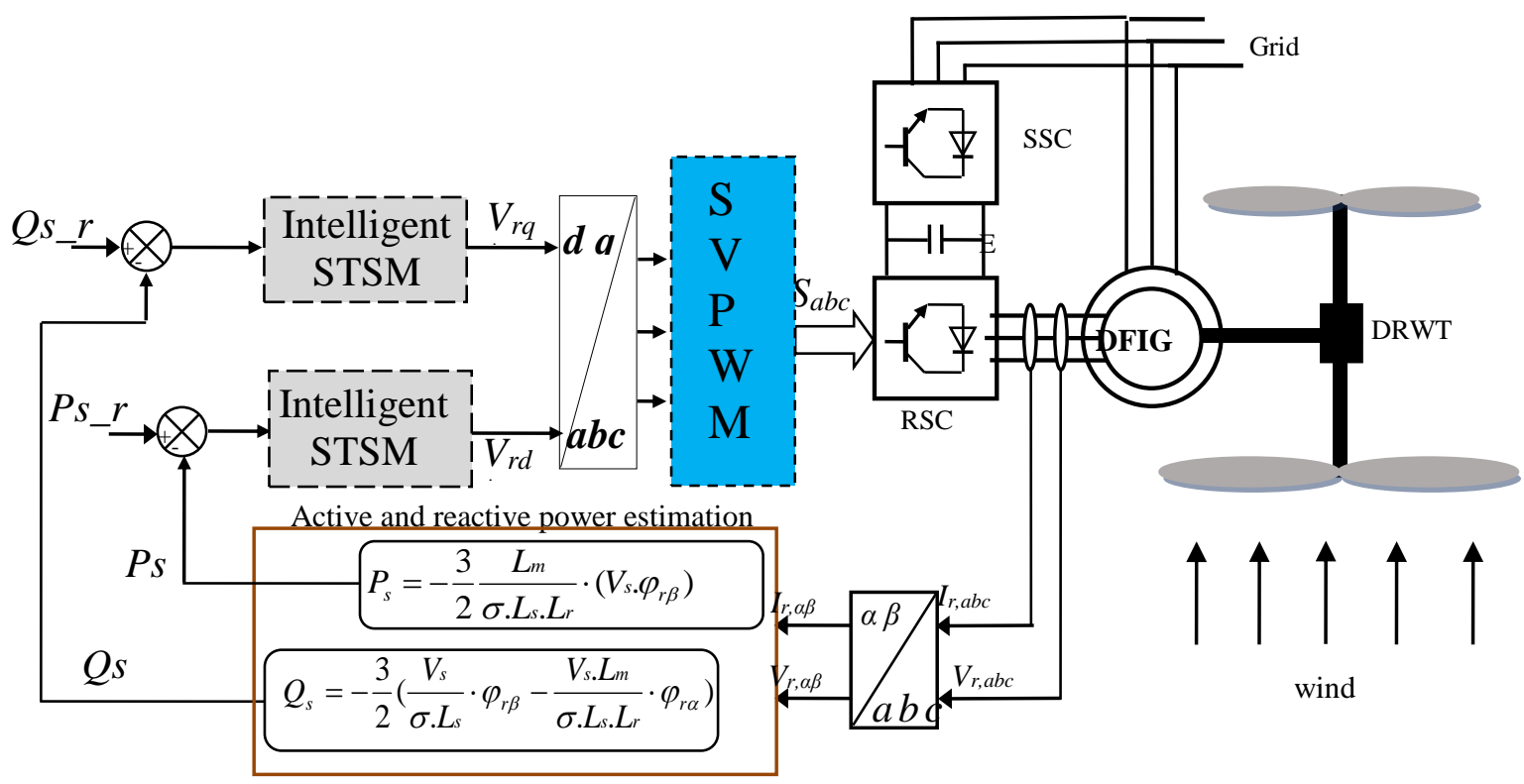

Figure 10. Block diagram DPC with intelligent STSM of DFIG-based DRWT.

Where $: \mathrm{V}_{\mathrm{s} \alpha}$ is the stator voltage linkage of $\alpha$-axis. 
$\mathrm{V}_{\mathrm{s} \beta}$ : is the stator voltage linkage of $\beta$-axis.

The stator flux amplitude is given by:

$$
\Phi_{s}=\sqrt{\Psi_{s \alpha}^{2}+\Psi_{s \beta}^{2}}
$$

The stator flux angle is calculated by :

$$
\theta_{s}=\operatorname{arctg}\left(\frac{\Psi_{s \beta}}{\Psi_{s \alpha}}\right)
$$

In the outer control loop of the DFIG power, the reference value of the reactive power is compared with the measured DFIG reactive power. The switching function for DFIG reactive power regulator can be specified as follows :

$$
S_{Q_{s}}=Q_{S_{\text {ref }}}-Q_{s}
$$

This controller determines the reference component $V^{*}{ }_{d r}$ of the reactive power vector (RPV), which is responsible for the command of the magnitude of the RPV. The output signal from the regulator of the magnitude of the RPV is determined by the following system of equations [67]:

$$
\left\{\begin{array}{c}
V_{d r}^{*}=K_{3}\left|S_{Q_{S}}\right|^{0.5} \operatorname{sgn}\left(S_{Q_{S}}\right)+V_{d r 1}^{*} \\
\frac{d V_{d r}^{*}}{d t}=K_{4} \operatorname{sgn}\left(S_{Q_{S}}\right)
\end{array}\right.
$$

In STSM algorithm, the switching function for active power vector (APV) regulator can be specified as follows:

$S_{P_{s}}=P_{S_{\text {ref }}}-P_{s}$

The output signal from the regulator of the magnitude of the APV is determined by the following system of equations $[66,67]$ :

$$
\left\{\begin{array}{c}
V_{q r}^{*}=K_{1}\left|S_{P_{S}}\right|^{0.5} \operatorname{sgn}\left(S_{P_{S}}\right)+V_{q r 1}^{*} \\
\frac{d V_{q r}^{*}}{d t}=K_{2} \operatorname{sgn}\left(S_{P_{S}}\right)
\end{array}\right.
$$

Table 3 shows the constants values of the active/reactive power STSM algorithm gains (K1, K2, K3 and K4).

TABLE 3

STSM CONTROLLER GAINES

\begin{tabular}{|l|l|l|l|l|l|}
\hline \multicolumn{2}{|c|}{ Reactive power } & \multicolumn{3}{|c|}{ Active power } \\
\hline K3 & K4 & r & K1 & K2 & r \\
\hline 200 & 1000 & 0.5 & 200 & 1000 & 0.5 \\
\hline
\end{tabular}

\section{RESULTS AND ANALYSIS}

The simulation results of DPC with ANFIS-STSM algorithms (DPC-ANFIS-STSM) of the DFIG are compared with DPC control with neural STSM algorithms (DPCNSTSM). For this end, the control system was tested under different tests.
The DFIG used in our study has the following parameters: nominal active power of the stator : $P_{s n}=1.5 \mathrm{MW}$, stator voltage : $380 / 696 \mathrm{~V}$, two poles, stator voltage frequency : $50 \mathrm{~Hz} ; R_{s}=0.012 \Omega, R_{r}=0.021 \Omega, L_{s}=0.0137 \mathrm{H}, L_{r}=$ $0.0136 \mathrm{H}, L_{m}=0.0135 \mathrm{H}, J=1000 \mathrm{~kg} \cdot \mathrm{m}^{2}$ and $f_{r}=0.0024 \mathrm{Nm} / \mathrm{s}$ [61-63].

\section{A. Reference tracking test (RTT)}

Figures 11-12 show the harmonic distortion of stator current of DFIG-based DRWTS obtained using FFT (Fast Fourier Transform) strategy for DPC-ANFIS-STSM method and DPC-NSTSM method respectively. It can be clearly observed that the THD is minimized for DPC-ANFIS-STSM method ( THD $=0.23 \%$ ) when compared to DPC-NSTSM (THD $=0.42 \%$ ). Table 4 shows the comparative analysis of the harmonic distortion of stator current.

The simulation waveforms of the reference and measured active power of the DFIG-based DRWTS are shown in Figure 13 in order to compare the performance of the DPC-ANFISSTSM method with the performance of the DPC-NSTSM method. The active power tracks almost perfectly their reference value $\left(P_{s-r e f}\right)$. On the other hand, the amplitudes of the oscillations of the active power are smaller and occur in a shorter time period in comparison with the oscillations obtained for the DPC-NSTSM method (see Figure 17).

For the DPC-ANFIS-STSM and DPC-NSTSM method, the reactive power track almost perfectly their reference value (see Figure 14). Moreover, the DPC-ANFIS-STSM method minimized the reactive power ripple compared to the DPCNSTSM method (See Figure 18).

The trajectory of the measured magnitude of the stator current is shown in Figure 16. It can be stated that the amplitudes of the stator currents depend on the state of the drive system and the value of the load active/reactive power of the DFIG-based WTS. In addition, the DPC-ANFIS-STSM method reduced the stator current ripple compared to the DPC-NSTSM method (See Figure 20). On the other hand, the DPC-ANFIS-STSM method reduced the response time of active power, reactive power and torque compared to DPCNSTSM method (see Table 5).

\section{TABLE 4}

COMPARATIVE ANALYSIS OF THD VALUE

\begin{tabular}{|l|c|c|}
\cline { 2 - 3 } \multicolumn{1}{c|}{} & \multicolumn{2}{c|}{ THD (\%) } \\
\cline { 2 - 3 } \multicolumn{1}{c|}{} & DPC-NSTSM & DPC-ANFIS-STSM \\
\hline Stator current & 0.42 & $\mathbf{0 . 2 3}$ \\
\hline
\end{tabular}

TABLE 5

COMPARATIVE ANALYSIS OF RESPONSE TIME

\begin{tabular}{|c|c|c|c|}
\cline { 2 - 4 } \multicolumn{1}{c|}{} & \multicolumn{3}{c|}{ Response time } \\
\cline { 2 - 4 } \multicolumn{1}{c|}{} & Torque & Active power & Reactive power \\
\hline DPC-NSTSM & $\mathbf{0 . 5 4 m s}$ & $\mathbf{0 . 5 4} \mathrm{ms}$ & $\mathbf{0 . 7 7} \mathrm{ms}$ \\
\hline DPC-ANFIS-STSM & $\mathbf{0 . 2 3} \mathrm{ms}$ & $\mathbf{0 . 2 3} \mathrm{ms}$ & $0.35 \mathrm{~ms}$ \\
\hline
\end{tabular}



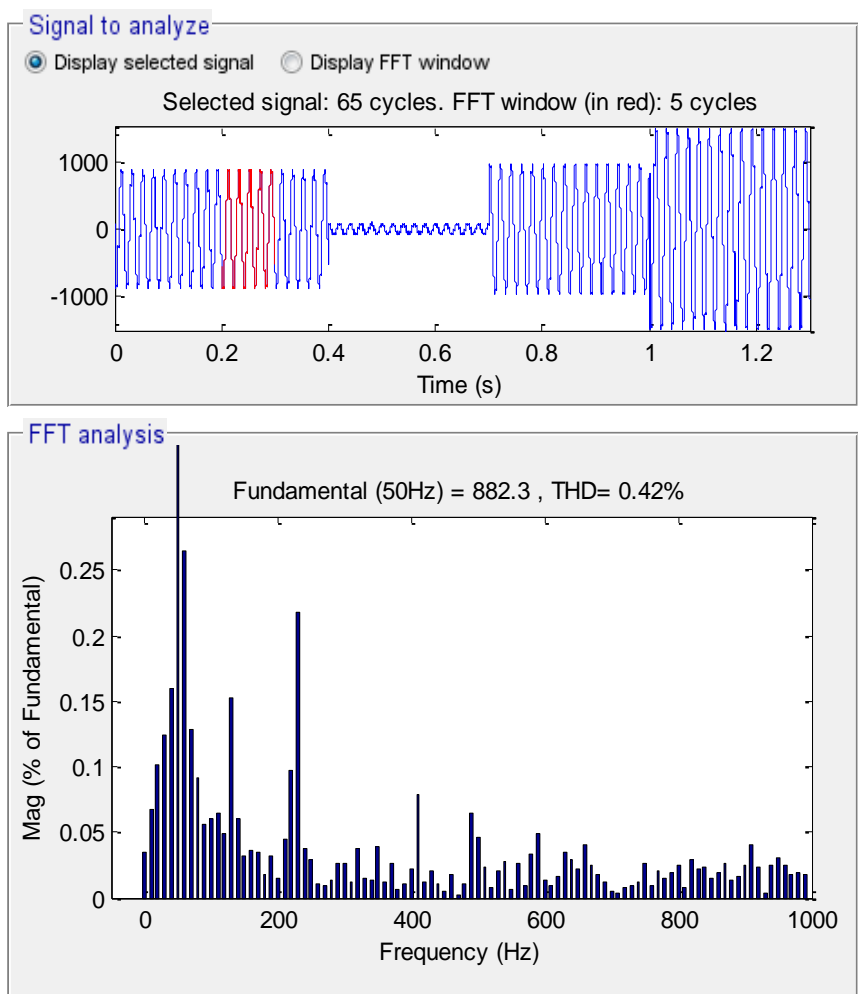

Figure 11. Spectrum harmonic of stator current (DPC-NSTSM).
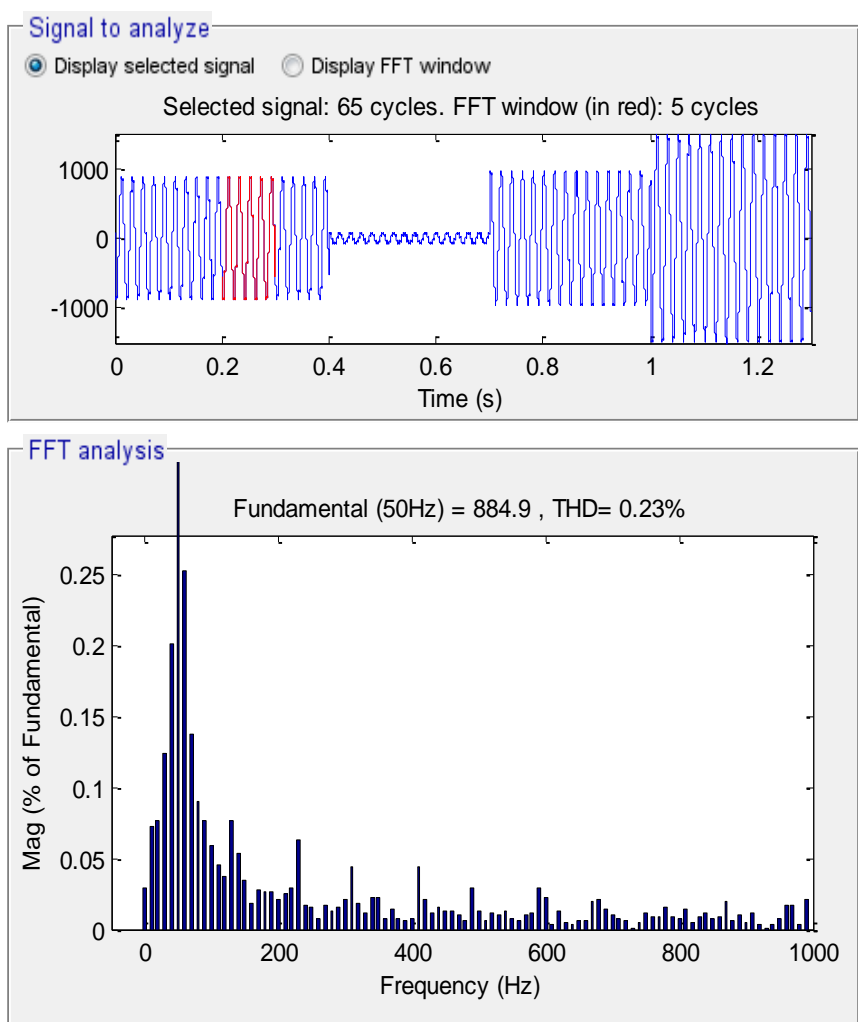

Figure 12. Spectrum harmonic of stator current (DPC-ANFIS-STSM).

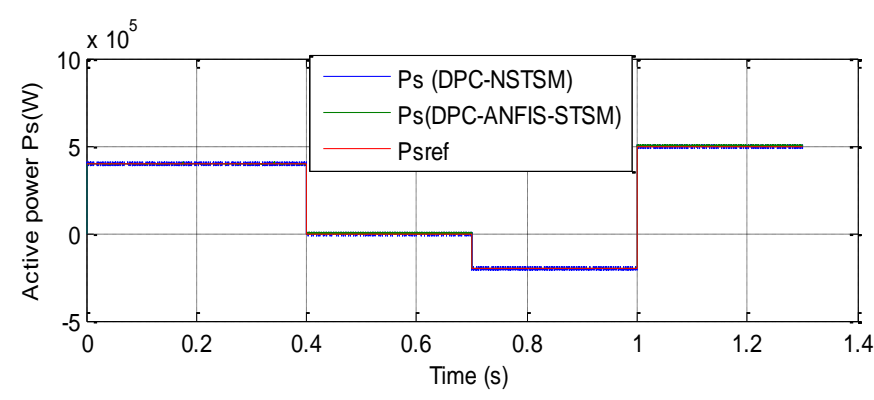

Figure 13. Active power (RTT).

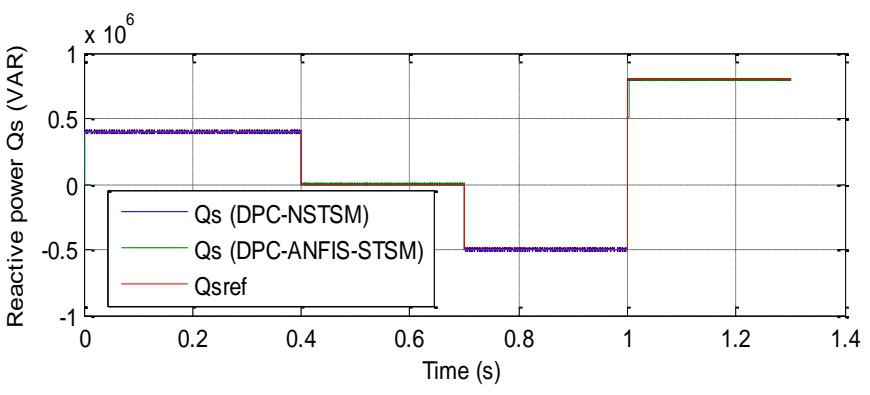

Figure 14. Reactive power (RTT).

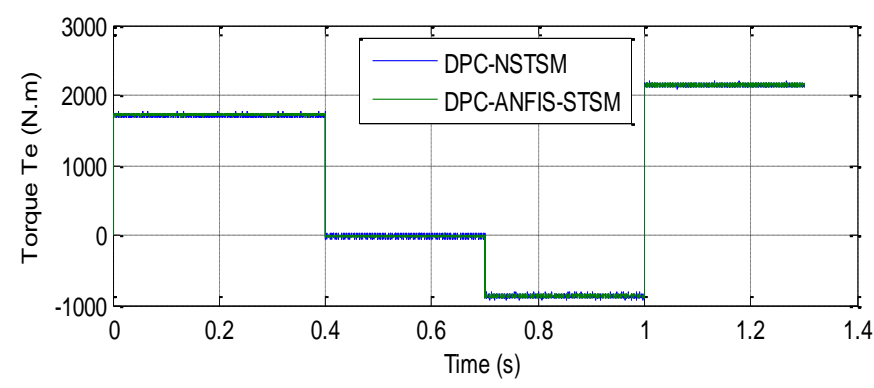

Figure 15. Torque (RTT).

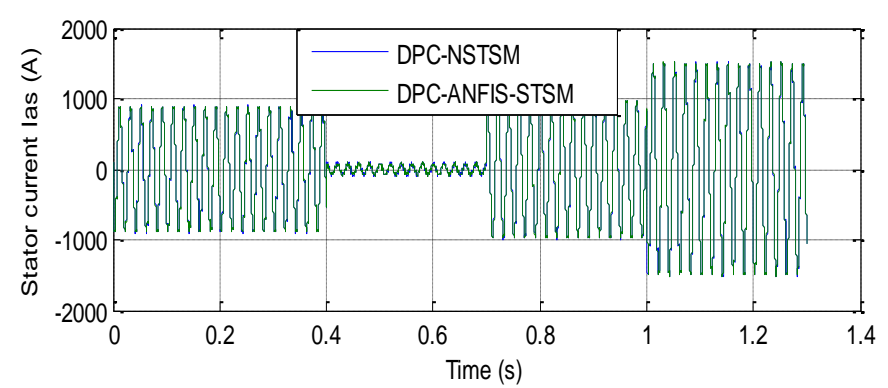

Figure 16. Stator currant (RTT).

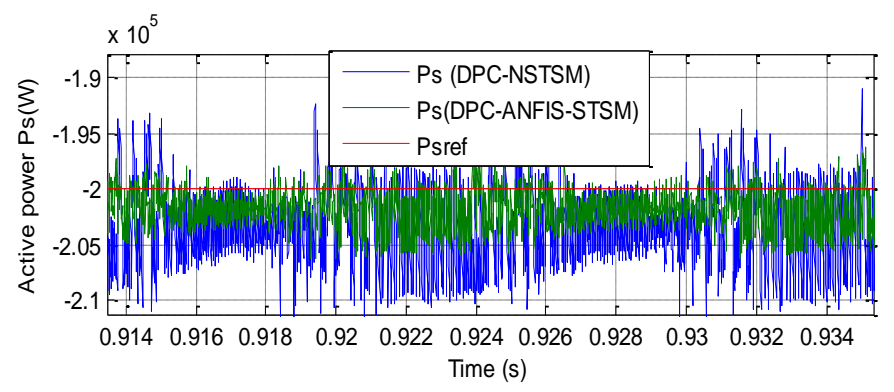

Figure 17. Zoom in the active power (RTT). 


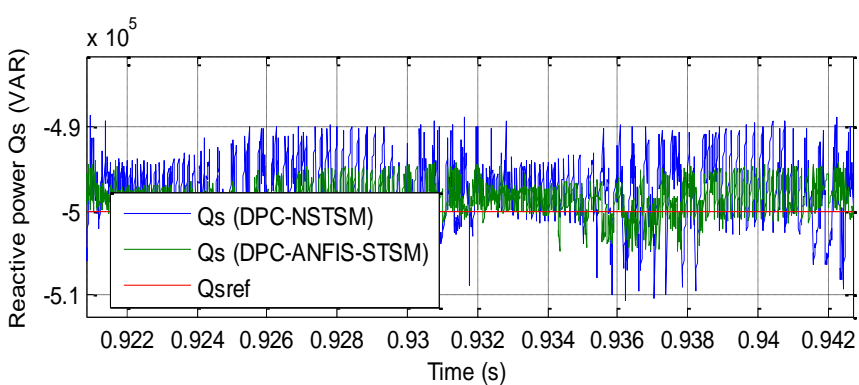

Figure 18. Zoom in the reactive power (RTT).

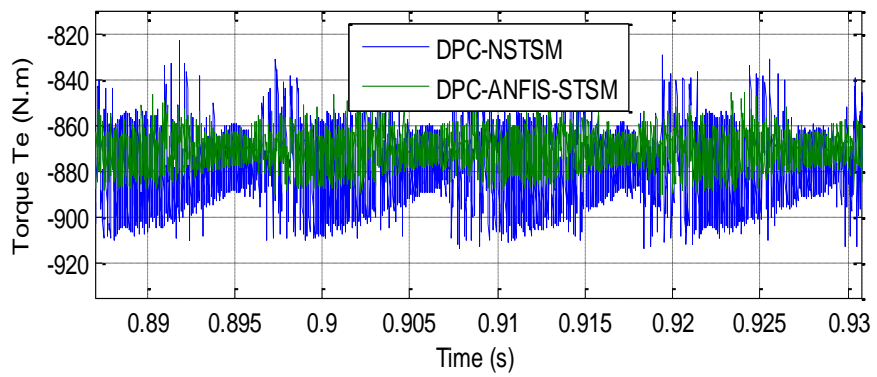

Figure 19. Zoom in the torque (RTT).

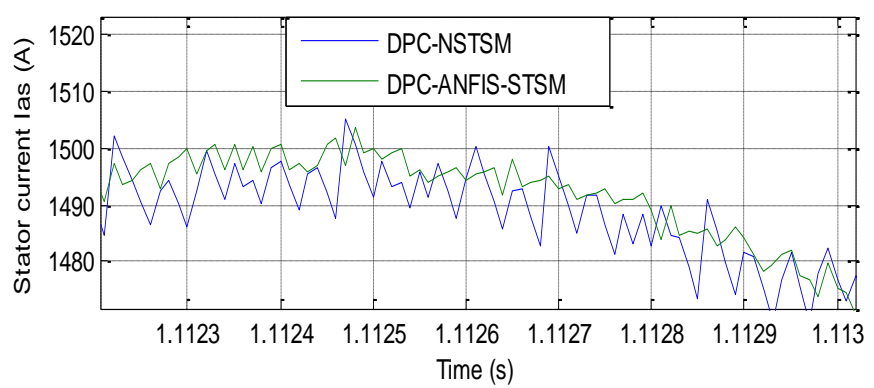

Figure 20. Zoom in the stator current (RTT).

\section{B.Robustness test (RT)}

In this part, the nominal values of $R_{r}$ and $R_{s}$ are multiplied by 2 and $L_{r}$ and $\mathrm{L}_{s}$ are multiplied by 0.5 . Simulation results are presented in Figures. 21-26. As it's shown by these figures, these variations present an apparent effect on reactive power, torque, active power and stator currents curves such as the effect appears more significant for the DPC-NSTSM method compared to DPC-ANFIS-STSM (See Figures 27-30).

The harmonic distortion of stator current in the DPCANFIS-STSM method has been minimized significantly (See Figures 21-22). Table 6 shows the comparative analysis of harmonic distortion of stator current. Thus it can be concluded that the proposed DPC-ANFIS-STSM method is more robust than the DPC-NSTSM method.

TABLE 6

COMPARATIVE ANALYSIS OF THD VALUE (RT)

\begin{tabular}{|c|c|c|}
\cline { 2 - 3 } \multicolumn{1}{c|}{} & \multicolumn{2}{c|}{ THD (\%) } \\
\cline { 2 - 3 } \multicolumn{1}{c|}{} & DPC-NSTSM & DPC-ANFIS-STSM \\
\hline Stator current & 0.54 & $\mathbf{0 . 2 9}$ \\
\hline
\end{tabular}
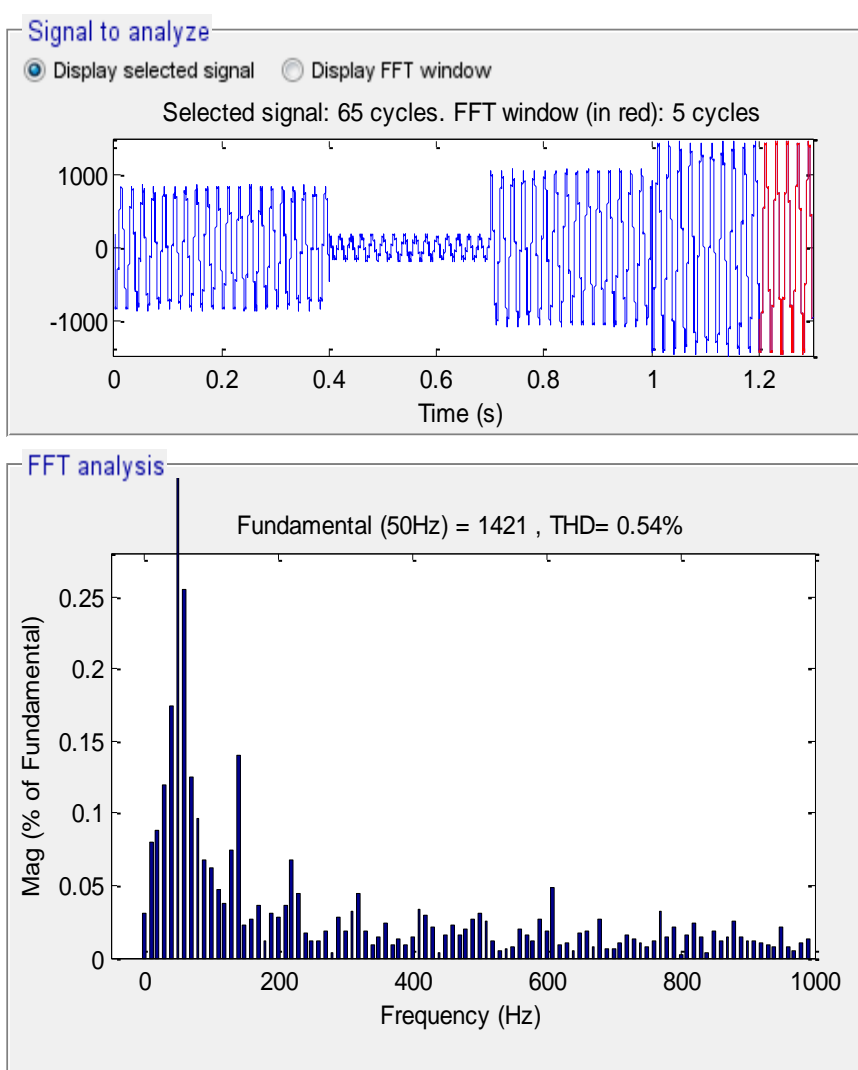

Figure 21. Spectrum harmonic of stator current (DPC-NSTSM).
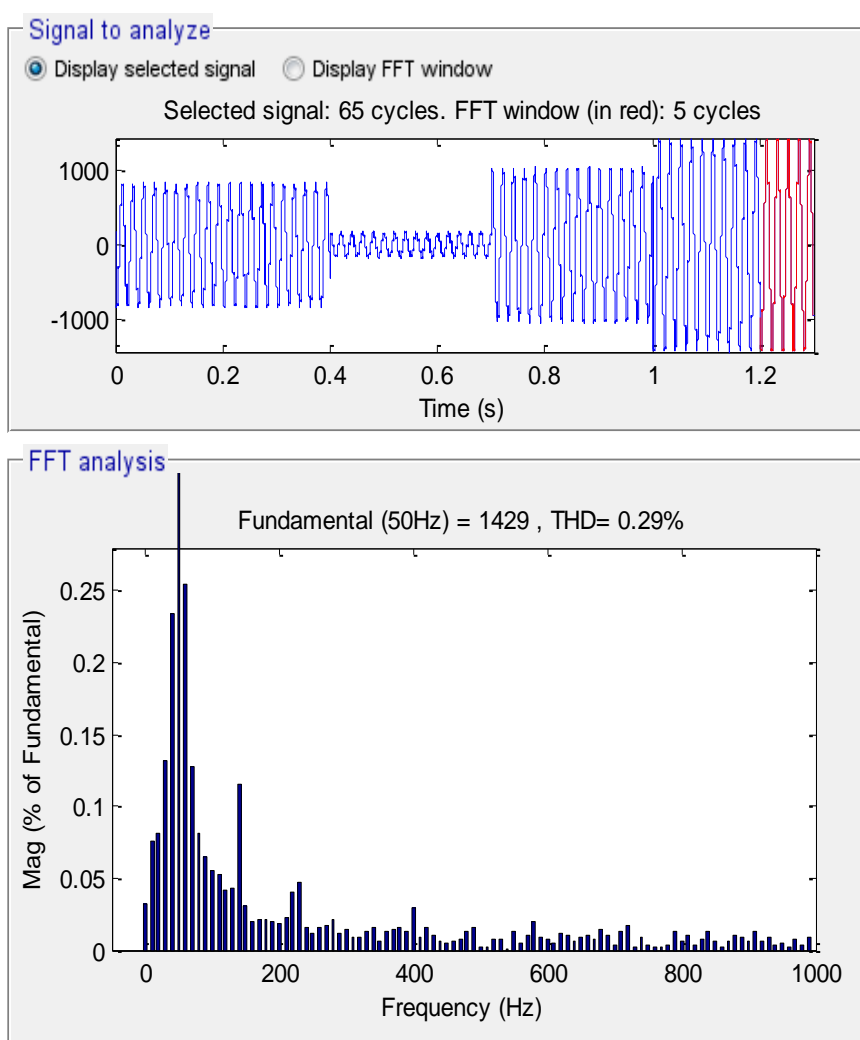

Figure 22. Spectrum harmonic of stator current (DPC-ANFIS-STSM). 


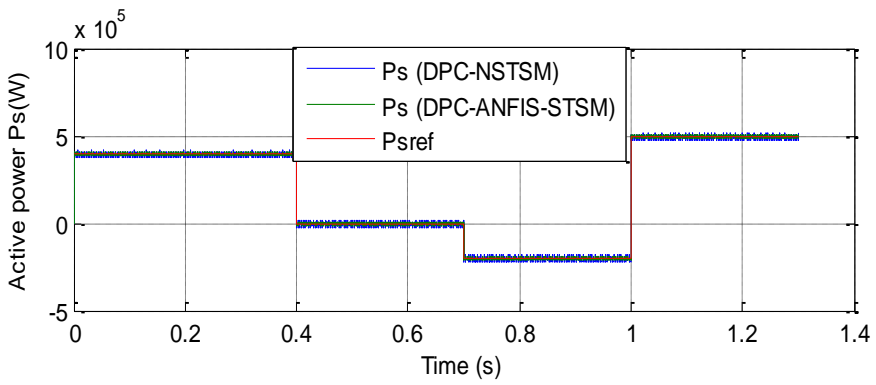

Figure 23. Active power (RT).

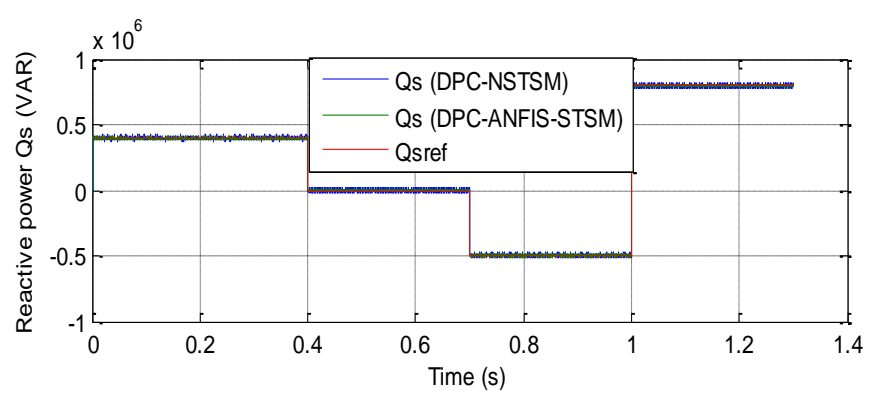

Figure 24. Reactive power (RT).

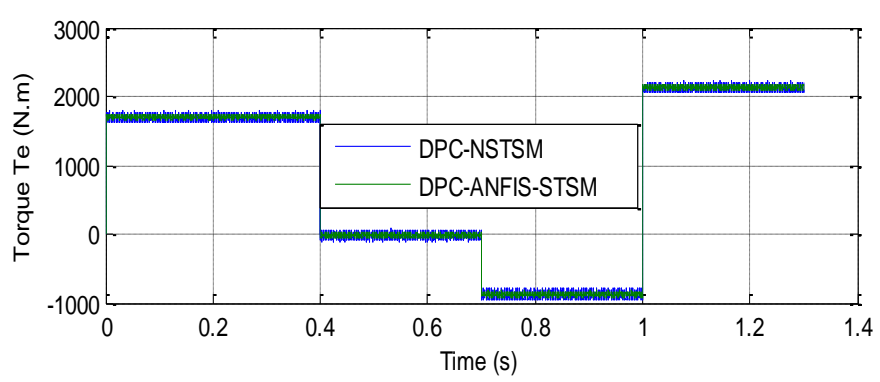

Figure 25. Torque (RT).

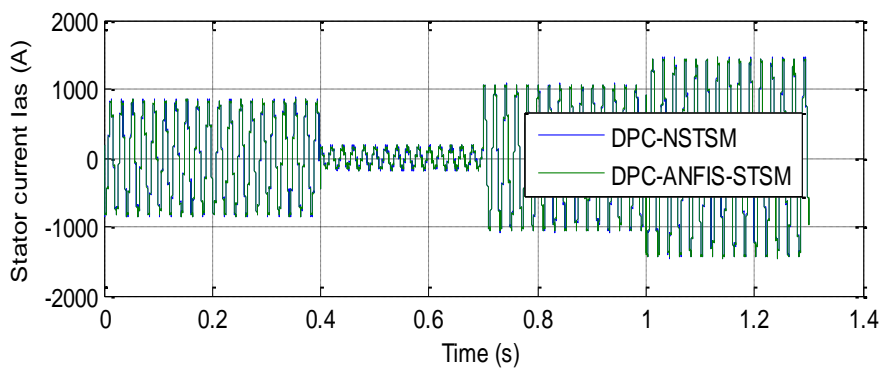

Figure 26. Stator current (RT).

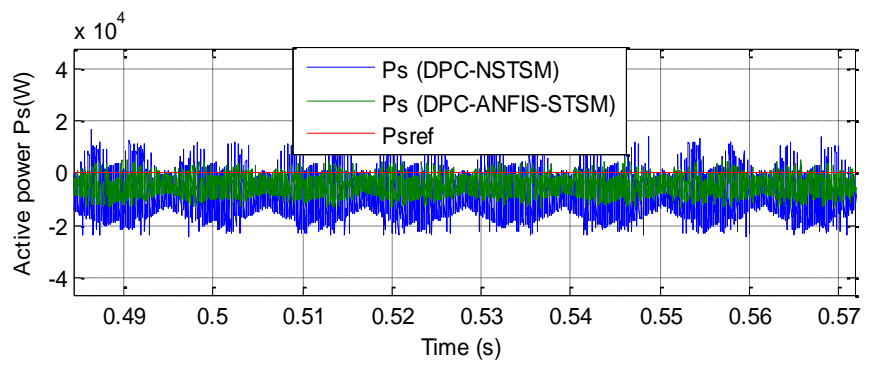

Figure 27. Zoom in the active power (RT)

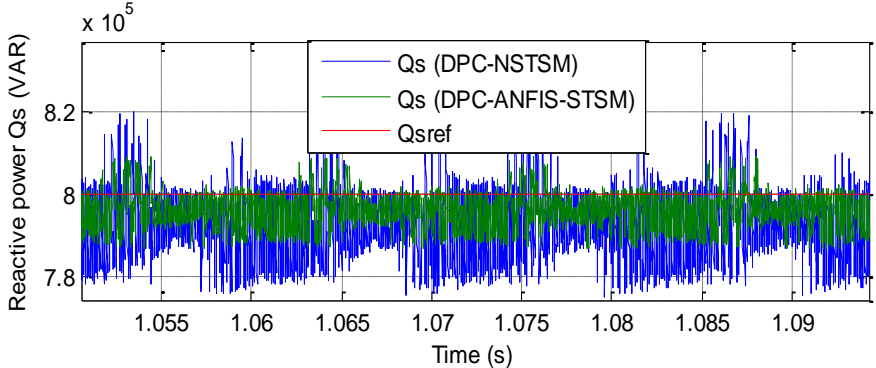

Figure 28. Zoom in the reactive power (RT).

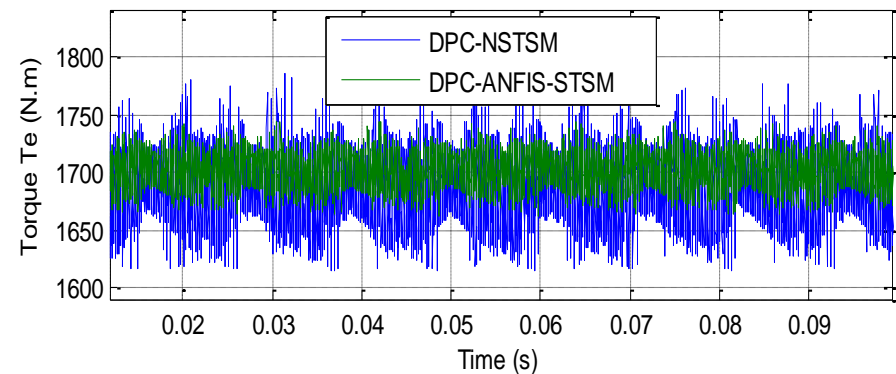

Figure 29. Zoom in the torque (RT).

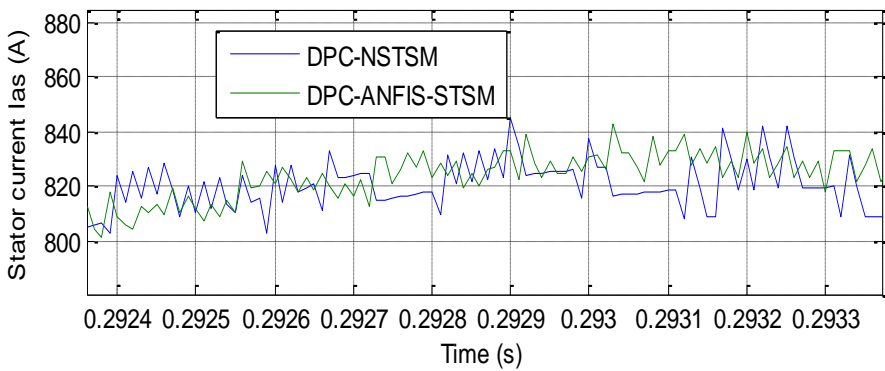

Figure 30. Zoom in the stator current (RT)

\section{CONCLUSIONS}

This work presents the simulation results of the DPC method of a DFIG-DRWT, using the two-level SVPWM technique compared with the ANFIS-STSM and neural STSM algorithms. Numerical simulations by Matlab/ Simulink have been developed to test the performances provided by the techniques used. With results obtained from the simulation, it is clear that for the same operation condition, the DPC method with ANFIS-STSM algorithm had good and good performance than the DPC method with neural STSM algorithm and that is clear in the reactive and active power ripples which the use of the ANFIS-STSM algorithm, it is minimized of ripples more than the neural STSM algorithm.

\section{REFERENCES}

[1] H. Benbouhenni, « Comparative Study between direct vector control and fuzzy sliding mode controller in three-level space vector modulation inverter of reactive and active power command of DFIGbased wind turbine systems, " International Journal of Smart Grid, Vol. 2, No. 4, pp. 188-196, 2018

[2] H. Benbouhenni, " Neuro-sconde order sliding mode field oriented control for DFIG based wind turbine, » International Journal of Smart Grid, Vol. 2, No. 4, pp. 209-217, 2018. 
[3] H. Benbouhenni, Z. Boudjema, A. Belaidi, «Neuro-second order sliding mode control of a DFIG supplied by a two-level NSVM inverter for wind turbine system, " Iranian Journal of Electrical \& Electronic Engineering, Vol. 14, No. 4, pp. 362-373, 2018.

[4] H. Benbouhenni, "New hybrid five-level space vector modulation strategy to minimize current distortion and power ripple for a DFIG controlled by NSOSMC control, " Majlesi Journal of Energy Management, Vol. 7, No. 2, 2018.

[5] H. Benbouhenni, " Comparative study between NSVM and FSVM strategy for a DFIG-based wind turbine system controlled by neurosecond order sliding mode, » Majlesi Journal of Mechatronic Systems, Vol. 7, No. 1, pp. 33-43, 2018.

[6] H. Benbouhenni, Z. Boudjema, A. Belaidi, «Higher control scheme using neural second order sliding mode and ANFIS-SVM strategy for a DFIG-based wind turbine, "International Journal of Advances in Telecommunications, Electrotechnics, Signals and Systems, Vol. 8, No. 2, pp. 17-28, 2019.

[7] H. Benbouhenni, « Comparison study between SVPWM and FSVPWM strategy in fuzzy second order sliding mode control of a DFIG-based wind turbine, " Carpathian Journal of Electronic and Computer Engineering, Vol. 12, No. 2, pp. 1-10, 2019.

[8] H. Benbouhenni, «Fuzzy second order sliding mode controller based on three-level fuzzy space vector modulation of a DFIG for wind energy conversion systems, » Majlesi Journal of Mechatronic Systems, Vol. 7, No. 3, pp.17-26, 2018.

[9] H. Benbouhenni, «A comparative study between FSMC and FSOSMC strategy for a DFIG-based wind turbine system,» Majlesi Journal of Mechatronic Systems, Vol. 8, No. 2, 2019.

[10] H. Benbouhenni, "Comparative study between PWM and SVPWM technique for a DFIG-based wind turbine system controlled by fuzzy sliding mode, » Majlesi Journal of Energy Management, Vol. 7, No. 4, 2018.

[11] H. Benbouhenni, Z. Boudjema, A. Belaidi, « Comparison study between NPWM and NSVPWM strategy in FSMC control of stator reactive and active powers control of a DFIG-based wind turbine system, » International Journal of Applied Power Engineering, Vol. 9, No. 2, pp. 159-172, 2020.

[12] H. Benbouhenni, «Sliding mode with neural network regulateur for DFIG using two-level NPWM strategy, » Iranian Journal of Electrical \& Electronic Engineering, Vol. 15, No. 3, pp.411-419, 2019.

[13] H. Benbouhenni, «Hybrid neural sliding mode control of a DFIG speed in wind turbines, » Majlesi Journal of Energy Management, Vol. 6, No. 4, pp. 31-41, 2017.

[14] H. Benbouhenni, «Comparison study between FPWM and NSVM inverter in neuro-sliding mode control of reactive and active power control of a DFIG-based wind energy, » Majlesi Journal of Energy Management, Vol. 6, No. 4, pp.15-23, 2017.

[15] H. Benbouhenni, Z. Boudjema, A. Belaidi, «A novel matlab/simulink model of DFIG drive using NSMC method with NSVM strategy, " International Journal of Applied Power Engineering, Vol. 8, No. 3, pp. 221-233, 2019.

[16]H. Benbouhenni, «A comparison study between fuzzy PWM and SVM inverter in NSMC control of stator active and reactive power control of a DFIG based wind turbine systems, » International Journal of Applied Power Engineering, Vol. 8, No. 1, pp. 78-92, 2019.

[17] H. Benbouhenni, «A comparative study between NSMC and NSOSMC strategy for a DFIG integrated into wind energy system, » Carpathian Journal of Electronic and Computer Engineering, Vol. 12, No. 1, pp. 1$8,2019$.

[18] H. Benbouhenni, «Second order sliding mode with ANFIS controllers for DFIG using seven-level NSVPWM technique, » Majlesi Journal of Energy Management, Vol. 8, No. 1, pp. 29-39, 2019.

[19] H. Benbouhenni, « ANFIS-sliding mode control of a DFIG supplied by a two-level SVPWM technique for wind energy conversion system, » International Journal of Applied Power Engineering, Vol. 9, No. 1, pp. $36-47,2020$.

[20] H. Benbouhenni, "Utilization of an ANFIS-STSM algorithm to minimize total harmonic distortion, » International Journal of Smart Grid, Vol. 4, No. 2, pp. 56-67, 2020.
[21] H. Benbouhenni, " Rotor flux and torque ripples minimization for direct torque control of DFIG by NSTSM algorithm, » Majlesi Journal of Energy Management, Vol. 7, No. 3, 2018.

[22] H. Benbouhenni, "Stator current and rotor flux ripples reduction of DTC DFIG drive using FSTSMC algorithm, » International Journal of Smart Grid, Vol. 3, No. 4, 2019.

[23] H. Benbouhenni, "A comparative study between DTC-NSTMC and DTC-FSTSMC control scheme for a DFIG-based wind turbine, " Majlesi Journal of Energy Management, Vol. 7, No. 4, 2018.

[24] J. Listwan, « Application of super-twisting sliding mode controllers in direct field-oriented control system of six-phase induction motor: experimental studies, » Power Electronics and Drives, Vol. 38, No. 3, No. 1, 2018

[25] I. Yaichi, A. Semmah, P. Wira, Y. Djeriri, «Super-twisting sliding mode control of a doubly-fed induction generator based on the SVM strategy, » Periodica Polytechnica Electrical Engineering and Computer Science, Vol. 63, No. 3, pp. 178-190, 2019.

[26] A. Bouyekni, R. Taleb, Z. Boudjema, H. Kahal, «A second-order continuous sliding mode based on DFIG for wind-turbine-driven DFIG, » Elektrotehniški Vestnik, Vol. 85, No. 1-2, pp. 29-36, 2018.

[27] A. Yahdou, B. Hemici, Z. Boudjema, " Sliding mode control of dual rotor wind turbine systel, " The Mediterranean Journal of Measurement and Control, Vol. 11, No. 2, pp. 412-419, 2015.

[28] H. Benbouhenni, Z. Boudjema, A. Belaidi, « Direct vector control of a DFIG supplied by an intelligent SVM inverter for wind turbine system, » Iranian Journal of Electrical and Electronic Engineering, Vol. 15, No. 1, pp. 45-55, 2019.

[29] H. Benbouhenni, Z. Boudjema, A. Belaidi, « Indirect vector control of a DFIG supplied by a two-level FSVM inverter for wind turbine system, » Majlesi Journal of Electrical Engineering, Vol. 13, No. 1, pp. 45-54, 2019.

[30] H. Benbouhenni, « Reducing current and torque ripples in DVC control of DFIG operation at constant switching frequency for wind generation application, » Majlesi Journal of Energy Management, Vol. 8, No. 4, pp. $47-55,2019$

[31] H. Benbouhenni, Z. Boudjema, A. Belaidi, « Using three-level Fuzzy space vector modulation method to improve indirect vector control strategy of a DFIG based wind energy conversion systems, " International Journal of Smart Grid, Vol. 2, No.3, pp.155-171, 2018.

[32] H. Benbouhenni, "Comparison study between seven-level SVPWM and two-level SVPWM strategy in direct vector control of a DFIGbased wind energy conversion systems, » International Journal of Applied Power Engineering, Vol. 9, No. 1, pp. 12-21, 2020.

[33] H. Benbouhenni, Zinelaabidine Boudjema, Abdelkader Belaidi, « Direct vector command based on three-level NSVM of a doubly fed induction generator for wind energy conversion, »IEEE Xplore, 2019.

[34] H. Benbouhenni, «Stator active and reactive power ripples minimization for DVC control of DFIG by using five-level neural space vector modulation, » Acta Electrotechnica et Informatica, Vol. 19, No. 2, pp.16-23, 2019.

[35] H. Benbouhenni, «Direct vector control for doubly fed induction generator-based wind turbine system using five-level NSVM and twolevel NSVM technique, » International Journal of Smart Grid, Vol. 3, No. 1, pp. 25-32, 2019.

[36] H. Benbouhenni, Z. Boudjema, A. Belaidi, « DFIG-based wind energy conversion system using five-level FSVM technique, " Int. J. Renewable Energy Technology, Vol. 11, No. 2, pp. 147-164, 2020.

[37] H. Benbouhenni, Z. Boudjema, A. Belaidi, «DFIG-based wind turbine system using four-level FSVM strategy, » Majlesi Journal of Energy Management, Vol. 6, No. 3, 2017.

[38] H. Benbouhenni, Z. Boudjema, A. Belaidi, « Intelligent SVM technique of a multi-level inverter for a DFIG-based wind turbine system, » Int. J. Digital Signals and Smart Systems, Vol. 3, Nos. 1/2/3, pp. 4-19, 2019.

[39] H. Benbouhenni, "Application of seven-level neural space vector PWM in direct vector control system of doubly fed induction generator for wind turbine, » International Journal of Smart Grid, Vol. 3, No. 3, pp. 163-171, 2019. 
[40] H. Benbouhenni, «Intelligence indirect vector control of a DFIG based wind turbines, " Majlesi Journal of Electrical Engineering, Vol. 13, No. 3, pp.27-35, 2019.

[41] H. Benbouhenni, Z. Boudjema, A. Belaidi, « Using four-level NSVM technique to improve DVC control of a DFIG based wind turbine systems, » Periodica Polytechnica Electrical Engineering and Computer Science, Vol. 63, No. 3, pp. 144-150, 2019.

[42] H. Benbouhenni, " Comparative study between different vector control methods applied to DFIG wind turbines, » Majlesi Journal of Mechatronic Systems, Vol. 7, No. 4, pp. 15-23, 2018.

[43] H. Benbouhenni, Z. Boudjema, A. Belaidi, "A comparative study between four-level NSVM and three-level NSVM technique for a DFIG-based WECSs controlled by indirect vector control, " Carpathian Journal of Electronic and Computer Engineering, Vol. 11, No. 2, pp. 13-19, 2018.

[44] H. Benbouhenni, Z. Boudjema, A. Belaidi, «DFIG-based WT system using FPWM inverter, » International Journal of Smart Grid, Vol. 2, No. 3, pp. 142-154, 2018.

[45] H. Benbouhenni, Z. Boudjema, A. Belaidi, « DFIG-based wind turbine system using three-level neural space vector modulation technique, » Majlesi Journal of Mechatronic Systems, Vol. 7, No. 2, pp. 35-45, 2018.

[46] H. Benbouhenni, «Direct vector control for doubly fed induction generator-based wind turbine system using five-level NSVM and twolevel NSVM technique, » International Journal of Smart Grid, Vol. 3, No. 1, pp. 25-32, 2019.

[47] H. Benbouhenni, «A new SVM scheme based on ANN controller of a PMSG controlled by DPC strategy, » Majlesi Journal of Energy Management, Vol. 7, No. 1, pp. 11-19, 2018.

[48] S. Jou, S. Lee, Y. Park, K. Lee, «Direct power control of a DFIG in wind turbines to improve dynamic responses, » J. Power Electron, Vol. 9, No. 5, pp. 781-790, 2009.

[49] E. G. Shehata, M. Gerges, M. Salama, «Direct power control of DFIGs based wind energy generation systems under distorted grid voltage conditions, » Electr. Power Energy Syst. Vol. 53, pp. 956-966, 2013.

[50] A. Kadri, H. Marzougui, F. Bacha, «Implementation of direct power control based on stator flux estimation using low-pass filter estimator for doubly fed induction generator-wind energy conversion system, Vol. 233, No. 7, pp. 764-778, 2019.

[51] L. Cartwright, P. Xu, «Direct active and reactive power control of DFIG for wind energy generation, » IEEE Trans. Energy Convers, Vol. 21, No. 3, pp. 750-758, 2006.

[52] S. Massoum, A. Meroufel, A. Massoum, P. Wira, "A direct power control of the doubly-fed induction generator based on the SVM strategy, » Elektrotehniski Vestnik, Vol. 45, No. 5, pp. 235-240, 2019.

[53] F. Amrane, A. Chaiba, «A novel direct power control for gridconnected doubly fed induction generator based on hybrid artificial intelligent control with space vector modulation, » Rev. Roum. Sci. Techn.-Electrotechn. Et Energ, Vol. 61, No. 3, pp. 263-268, 2016.

[54] R. Tiwaria, Ka. Kumar, N. B. Ramesh, K. R. Prabhu, «Coordinated MPPT and DPC strategies for PMSG based grid connected wind energy conversion system, » Energy Procedia, Vol. 145, pp. 339-344, 2018.

[55] A. Jain, S. Shankar, V. Vanitha, «Power generation using permanent magnet synchronous generator (PMSG) based variable speed wind energy conversion system (WECS): An overview, » Journal of Green Engineering, Vol. 74, pp. 477-504, 2018.

[56] P. Q. Dzung, A. N. Bao, P. L. Minh, H. H. Dinh, H. H. Lee, « The implementation of direct virtual torque control and direct power control for DFIG in wind energy system using dSPACE 1103, I IEEE PEDS 2011, Singapore, 5 - 8 December 2011.

[57] A. Izanlo, S. A. Gholamian, M. V. Kazemi, "Comparative study between two sensorless methods for direct power control of doubly fed induction generator, » Rev. Roum. Sci. Techn.-Electrotechn. Et Energ, Vol. 62, No. 4, pp. 358-364, 2017.

[58] S. M. Tavakoli, M. A. Pourmina, M. R. Zolghadri, «Comparison between different DPC methods applied to DFIG wind turbines, " International Journal of Renewable Energy Research, Vol. 3, No.2, pp. 446-452, 2013.

[59] H. Benbouhenni, Z. Boudjema, A. Belaidi, «Power control of DFIG in WECS using DPC and NDPC-NPWM methods, " Mathematical
Modelling of Engineering Problems, Vol. 7, No. 2, pp. 223-236, 2020.

[60] H. Benbouhenni, «Twelve sectors DPC control based on neural hysteresis comparators of the DFIG integrated to wind power, " Tecnica Italiana-Italian Journal of Engineering Science, Vol. 64, No. 2, pp. 223-236, 2020.

[61] H. Benbouhenni, Z. Boudjema, A. Belaidi, « Power ripple reduction of DPC DFIG drive using ANN controller, " Acta Electrotechnica et Informatica, Vol. 20, No. 1, pp.15-22, 2020.

[62] H. Benbouhenni, «Direct power control of a DFIG fed by a seven-level inverter using SVM strategy, " International Journal of Smart Grid, Vol. 3, No. 2, pp. 54-62, 2019.

[63] H. Benbouhenni, « Application of five-level NPC inverter in DPCANN of doubly fed induction generator for wind power generation systems, » International Journal of Smart Grid, Vol. 3, No. 3, pp. 128137, 2019

[64] H. Benbouhenni, «A direct power control of the doubly fed induction generator based on the three-level NSVPWM technique, » International Journal of Smart Grid, Vol. 3, No. 4, 2019

[65] H. Benbouhenni, Z. Boudjema, A. Belaidi, « Sensorless twelve sectors implementation of neural DPC controlled DFIG for reactive and active powers ripples reduction, " Majlesi Journal of Energy Management, Vol. 7, No. 2, 2018.

[66] H. Benbouhenni, Z. Boudjema, A. Belaidi, «Direct power control with NSTSM algorithm for DFIG using SVPWM technique, " Iranian Journal of Electrical \& Electronic Engineering, Vol. 17, No. 1, 2021.

[67] H. Benbouhenni, Z. Boudjema, A. Belaidi, «DPC based on ANFIS super-twisting sliding mode algorithm of a doubly-fed induction generator for wind energy system, " Journal Européen des Systèmes Automatisés, Vol. 53, No. 1, pp. 69-80, February, 2020.

[68] M. V. Kazemi, A. S. Yazdankhah, H. M. Kojabadi, «Direct power control of DFIG based on discrete space vector modulation,» Renewable Energy, Vol. 35, pp. 1033-1042, 2010.

[69] H. Benbouhenni, Z. Boudjema, "Two-level DTC based on ANN controller of DFIG using 7-level hysteresis command to reduce flux ripple comparing with traditional command, » IEEE Xplore, 2019.

[70] H. Benbouhenni, « Torque Ripple Reduction of DTC DFIG Drive using Neural PI Regulators, » Majlesi Journal of Energy Management, Vol. 8, No. 2, pp. 21-26, 2019.

[71] A. Yahdou, B. Hemici, Z. Boudjema, «Second order sliding mode control of a dual-rotor wind turbine system by employing a matrix converter, » Journal of Electrical Engineering, Vol. 16, No. 4, pp. 1-11, 2016.

[72] H. Benbouhenni, Rachid Taleb, «Commande directe du couple neuronale à 6 secteurs de la machine asynchrone alimentée par onduleur NPC à sept niveaux, » Revue Proceedings of Engineering and Technology (PET), Vol.14, pp. 137-142, 2017.

[73] H. Benbouhenni, «Etude Comparative entre la commande DTC neuronale et la commande DTC basée sur le contrôleur PI-neuronale de la machine asynchrone, » Rev. Ivoir. Sci. Technol., Vol. 29, pp. 30-43, 2017.

[74] H. Benbouhenni, «Seven-level direct torque control of induction motor based on artificial neural networks with regulation speed using fuzzy PI controller, " Iranian Journal of Electrical and Electronic Engineering, Vol. 14, No.1, pp. 85-94, 2018.

[75] H. Benbouhenni, «Five-level DTC with 12 sectors of induction motor drive using neural networks controller for low torque ripple, » Acta Electrotechnica et Informatica, Vol. 18, No. 2, pp. 61-66, 2018.

[76] H. Benbouhenni, «Five-level DTC based on ANN of IM using 13-level hysteresis control to reduce torque ripple comparing with conventional control, » Acta Technica Corviniensis-Bulletin of Engineering, Vol. 11, No. 2, pp. 55-58, 2018.

[77] H. Benbouhenni, «Four-level direct torque control of permanent magnet synchronous motor based on neural networks with regulation speed using neural PI controller, " Majlesi Journal of Mechatronic Systems, Vol. 8, No. 4, pp. 1-10, 2019.

[78] J. S. R. Jang, «ANFIS: Adaptive-Network-Based Fuzzy Inference System, »IEEE Transactions on Systems Man \& Cybernetics, Vol. 23, pp. 665-685, 1993. https://doi.org/10.1109/21.256541. 
[79] P. Melin, O. Castillo, «Intelligent control of complex electrochemical systems with a neuro-fuzzy-genetic approach. IEEE Trans, » Industrial Electronics, Vol. 48, No. 5, pp.951-955, 2001.

[80] Y. Sun, J. Xu, H. Qiang, G. Lin, «Adaptive neural-fuzzy robust position control scheme for Maglev train systems with experimental verification,» IEEE Trans. on Industrial Electronics, Vol. 66, No. 11, pp. 8589-8599, 2019.

[81] H. Benbouhenni, «Fuzzy speed controller of induction machine with 36 sectors DTC based ANFIS hysteresis comparator, » Majlesi Journal of Mechatronic Systems, Vol. 8, No. 3, pp. 1-8, 2019.

[82] H. Benbouhenni, «ANFIS speed controller of IM drives with threelevel DTC-based neural network, » Majlesi Journal of Mechatronic Systems, Vol. 8, No. 1, pp. 11-17, 2019.

[83] H. Benbouhenni, «Six sectors DTC control of IM drives based on ANN with regulation speed using ANFIS controller, » ANNALS of Faculty Engineering Hunedoara-International Journal of Engineering, Vol. 16, No. 4, pp. 69-73, 2018.

\section{Creative Commons Attribution License 4.0 (Attribution 4.0 International, CC BY 4.0)}

This article is published under the terms of the Creative Commons Attribution License 4.0

https://creativecommons.org/licenses/by/4.0/deed.en_US 